\title{
Pengembangan Model Total Suspended Matter (TSM) Menggunakan Data Satelit SPOT 6 (Studi Kasus : Di Muara Sungan Citanduy, Segara Anakan)
}

\author{
Model Development of Total Suspenden Matter (TSM) Using SPOT 6 Satellite Data \\ (Case Study: In Citanduy River Estuary, Segara Anakan)
}

\author{
Nana Suwargana \\ Pusat Pemanfaatan Penginderaan Jauh LAPAN \\ e-mail: nana.suwargana@gmail.com
}

\begin{abstract}
Abstrak
Analisis data penginderaan jauh dengan menggunakandata satelit SPOT 6dapat digunakan untuk melihat dinamika fluktuasi besarnya Total Suspended Matter (TSM). Dalam penelitian ini telah dilakukan pengembangan model ekstraksi TSM dengan studi kasus di muara sungaiCitanduy yang merupakan salah satu penyebab proses pendangkalan dikawasan perairan Segara Anakan.Tujuan penelitian ini adalah pengembangan model TSM yang diekstraksi dari data satelit SPOT 6. Metode penelitian adalahmenggunakan pendekatan algoritma dari persamaan fungsi ekponensial satu kanal band merah dari data satelit SPOT 6,dimana nilai reflektansi data band merah yang sudah terkoreksi atmosfer. Hasil analisis menunjukkan bahwa kanal merah sensitif terhadap nilai konsentrasi TSM, terbukti dapat memberikan identifikasi nilai konsentrasi TSM yang baik. Berdasarkan hasil test area sebanyak 28 titik pengamatan dapat menunjukkan nilai koefesien determinasi $\mathrm{R}^{2}=0,903 \%$ ini menunjukkan suatu hasil yangsignifikan.
\end{abstract}

Kata Kunci: Kanal merah, Panjang gelombang, SPOT 6dan TSM .

\begin{abstract}
Analysis of remote sensing data using satellite data SPOT 6 can be used to look at the dynamics of fluctuations in the amount of Total Suspended Matter (TSM). In this research has made the development of extraction model TSM with a case study on the estuary Citanduy which is one cause silting process waters Segara Anakan region. The purpose of this research is the development of a model TSM extracted from SPOT 6 satellite data. The method is to use the algorithm of equation approaches exponential function of the red band channels of SPOT 6 satellite data, in which the red band reflectance values of data that have been corrected atmosphere. The analysis showed that the channel red is sensitive to the concentration value of the TSM, proven to provide identification of TSM concentration was good value. Based on the results of the test area as much as 28 observation points can demonstrate the value of determination coefficient $\mathrm{R} 2=0.903 \%$ showed a significant result.
\end{abstract}

Keywords: Red Channel, SPOT 6, TSMand Wavelength. 


\section{Pendahuluan}

Kawasan perairan muara sungai perupakan suatu kawasan yang sangat dipengaruhi oleh lingkungan di sepanjang DAS tersebut. Banyak faktor yang mempengaruhi terhadap kawasan tersebut.Diantaranya adalah kegiatan pertanian, pertambakan dan segala aktivitas di sekitar kawasan tersebut menyangkut kegiatan domistik dan industri yang berkaitan dengan pencemaran dan sedimentasi Parwati, et.al., (2006). Salah satu kawasan yang banyak tercemar olehkerusakan lingkungan adalah kawasan SagaraAnakan yang sangat dipengaruhi oleh beberapa sungai yang mengalir di kawasan ini. Informasi utama yang dapat diperoleh di Segara Anakan adalah makin sempitnya laguna yang sangat berkaítan dengan tíngginya laju sedimentasi di wilayah tersebut.Padahal laguna tersebut merupakan andalan berlangsungnya beberapa kegiatan utama di wilayah tersebut, antara lain perikanan, pelayaran, pariwisata dan tentu saja fungsi ekologis yang sangat tinggi. Hal ini tentu saja menarik perhatian pada stakeholder baik yang berhubungan secara langsung maupun secara tidak langsung di kawasan tersebut. Banyak kajian, diskusi dan hal-hal teknis yang dibicarakan menyangkut usaha penyelamatan laguna. Salah satunya adalah kegiatan inventarisasi aspek-aspek fisik wilayah setempat yang nantinya akan digunakan untuk memprediksi kondisi laguna beberapa tahun mendatang.

Kawasan muara Citanduy yang merupakan aliran air sungai kelaguna Sagara Anakan merupakan suatu kawasan yang tidak berdiri sendiri. Kawasan tersebut berupa estuari yang terlindungi dan dikelilingi oleh hutan mangrove yang perkembangannya sangat dinamís. Dí wilayah tersebut terdapat tiga sungai besar sumber pembawa lumpur yang bermuara dí kawasan laguna tersebut, yaítu Sungai Citanduy, Cíbeureum, dan Cimeneng. Sedimentasi TSM (Total Suspended Matter/Total Padatan Tersuspensi) yang merupakan salah satu penyebab proses pendangkalan kawasan perairan Segara Anakan sangat dipengaruhi oleh erosi yang terjadi pada daerah aliran sungai kawasan ini. Tingginya nilai TSM menunjukkan tingginya tingkat pencemaran yang dapat menghambat penetrasi cahaya ke dalam air sehingga mengakibatkan terganggunya proses fotosintesis dari biota air (Parwati et al., 2014).
Oleh karena itu, data penginderaan jauh sangatlah diperlukan untuk mendeteksi areal yang sangat luas dan diperlukan metode yang baik untuk mendapatkan hubungan antara konsentrasi TSM dengan reflektansi yang diterima oleh sensor satelit.TSM merupakan material tersuspensi (diameter $>1 \mu \mathrm{m}$ ) yang tertahan pada saringan millipore (diameter pori $0,45)$ dan terdiri dari lumpur, pasir halus dan jasad-jasad renik (Effendi, 2003). TSM sering dilakukan untuk mengetahui kualitas air, karena nilai TSM yang tinggi menunjukkan tingginya tingkat pencemaran dan menghambat penetrasi cahaya ke dalamair sehingga mengakibatkan terganggunya proses fotosintesis dari biota air.

Menurut Tassan, (1993), TSM dapat dideteksi dengan menggunakan Band 2 (band hijau) dari citra Landsat-TM. Alasan menggunakan band 2 kisaran panjang gelombang 0.52-0.56 $\mu \mathrm{m}$ lebih sensitif dalam mendeteksi TSM.Kemudian telah banyak dilakukan oleh para peneliti sebelumnya seperti oleh Achiruddin, dkk (2005), dengan menggunakan citra Landsat multi-temporal tahun 1994, 2000 dan 2002, yang dilakukan di Pantai TimurSurabaya, hasilnyatelah terjadi sedimentasiberupa penambahan daratan dengan tutupan lahan berupa tambak. Sedangkan Carolita, dkk (2005) dalam penelitiannya di Segara Anakan Kabupaten Cilacap Jawa Tengah menggunakan citra Landsat tahun 1978, 1998 dan 2003 menunjukkan bahwa dalam kurun waktu tersebut di kawasan Segara Anakan telah terjadi sedimentasi yang begitu besar ditunjukkan dengan semakin menyempitnya laguna. Kemudian Budiman (2004) telah melaporkan bahwa penelitian TSM yang dilakukannyamenggunakan persamaan bentuk fungsi eksponensialdengan kanal yang digunakan adalah kanal band merah pada satelit ASTER.Algoritma untuk konsentrasi TSM tersebut menggunakan bio-optical model dapat digunakan untuk menghasilkan data set $\mathrm{R}(0-)$ pada setiap senssor kanal sebagai fungsi dari meningkatnya konsentrasi TSM. Hubungan yang dibangun sejak awal penelitian adalah korelasi antara nilai TSM dan nilai spektral pada masing-masing kanal, sehingga algoritma yang digunakan adalah algoritma berdasarkan pada satu kanal.

Data penelitian yang digunakan dalam penelitian ini adalah citra satelit dataSPOT-6. Data SPOT-6 membawa sensor NAOMI (New 
AstroSat Optical Modular Instrument) dengan resolusi spasial lebih tinggi dibandingkan sensor HRVIR SPOT-4 dan HRG SPOT-5 yang beroperasi sebelumnya, yakni $1,5 \mathrm{~m}$. SPOT-6/7 merupakan generasi satelit mempunyai resolusi spasial tertinggi saat ini dari seri satelit SPOT. Sensor NAOMI bekerja pada panjang gelombang kanal spektral lebih lebar daripada kanal Pankromatik SPOT-4 dan SPOT-5, yakni $0,450-0,745 \mu \mathrm{m}$, sedangkan kanal multi spektral dengan resolusi spasial $6 \mathrm{~m}$ terdiri dari kanal spektral biru $(0,450$ $0,520 \mu \mathrm{m})$, hijau $(0,530-0,590 \mu \mathrm{m})$, merah $(0,625-0,695 \mu \mathrm{m})$ dan NIR $(0,760-0,890 \mu \mathrm{m})$. SPOT-6 merupakan satelit generasi SPOT pertama yang mempunyai kanal spektral warna biru. Kanal spektral biru berpotensi mempertegas batas tepi pantai, sedimentasi laut, dan mendeteksi terumbu karang yang sulit dideteksi oleh kanal multi spektral lainnya. Dari sisi spasial SPOT-6 cukup bagus karena akan bisa menghasilkan peta dengan skala 1:10.000-1:20.000.

Pada kegiatan penelitian ini perlu dilakukan pengembangan model ekstraksi TSM dengan menggunakan data citra SPOT 6 di Muara Sungai Citanduy, Segara Anakan. Pemilihan wilayah Muara Sungai Citanduy, Segara Anakan karena wilayah tersebut memiliki potensi ekonomi yang besar. Secara ekologis wilayah ini dipisahkan oleh Daerah Aliran Sungai (DAS) tersendiri, dan memiliki perairan laguna yang luas terhalang oleh pulau karang Nusakambangan, yang memisahkan dari Samudra Indonesia. Nilai strategis lain dari wilayah muara Citanduy adalah lokasi geografisnya sebagai pintu gerbang antar perbatasan Jawa Barat dan Jawa Tengah. Oleh karena itu, penataan ruang dan pengelolaan wilayah muara Segara Anakan dapat lebih diprioritaskan. Dengan demikian, wilayah ini akan memiliki peluang untuk lebih maju dan berkelanjutan serta akan lebih berperan bagi dua Provinsi Jawa Barat dan Jawa Tengah secara keseluruhan.Kegiatan penelitian ini bertujuan untuk memberikan kontribusi dalam pengetahuan tentang perairan muara-muara sungai di Indonesia yang mengalami gangguan dari berbagai aktivitas manusia (penggundulan hutan, polusi, perubahan penggunaan lahan, dll). Adapun penelitian ini akan memanfaatkan data satelit SPOT 6 untuk membuat model distribusi TSM dan sebagai studi kasus penelitian adalah muara sungai Citanduy.Reflektansi citra yang digunakan adalah data SPOT 6 adalah kanal 3, yaitu kanal visibleband merah, dengan panjang gelombang $0.636-0.673 \mathrm{~m}$.

\section{Bahan dan Metode}

\section{Lokasi dan Bahan}

Lokasi penelitian dilakukan di kawasan kanal barat Segara Anakan tepatnya di muara sungai Citanduy hingga ke laut lepas pantai Samudra Hindia, terletak antara Kabupaten Pangandaran, Propinsi Jawa Barat dan Kabupaten Cilacap, Propinsi Jawa Tengah ditunjukkan pada Gambar 1. Secara geografis terletak pada koordinat $7^{0} 41^{\prime} 17.98-7^{0} \quad 43^{\prime}$ 43.22 LS dan $108^{0} 44^{\prime} 35.14-108^{\circ} 47^{\prime} 18.62$ BT. Segara Anakan terlindung oleh pulau karang Nusakambangan, yang memisahkan dari Samudra Indonesia. Meskipun demikian, Segara Anakan tetap berhubungan dengan Samudera Indonesia melalui dua kanal, yaitu kanal timur dan kanal barat. Kedua kanal ini menyebabkan Segara Anakan tetap berpengaruh oleh gerakan pasang surut Samudera Indonesia. Kanal timur berupa kanal sempit, panjang dan dangkal. Sedangkan kanal barat berukuran lebih dalam dan lebar, sehingga kanal barat lebih berperan dalam interaksi pasang surut yang merupakan sebagai kasus dalam penelitian model analisis TSM.

Bahan yang digunakan dalam penelitian ini adalah data inderaja SPOT 6 aquisisi tanggal10 Januari 2015 dengan karakteristik bisa dilihat pada Tabel 1.Data pendukung lainnya adalah Peta Rupa Bumi Skala 1:250.000. Waktu pengambilan sample diambail 24 titik pengamatan mulai dari Sungai Citanduy, muara Sungai Cibeureum dan Sungai Cimeneng. Gambar 1 menunjukkan sebaran titik-titik pengamatan untuk pengambilan sampel data reflektansi untuk pengolahan TSM yang diplot pada citra SPOT 6 . 
Nana Suwargana :Pengembangan Model Total Suspended Matter (TSM) Menggunakan Data Satelit SPOT 6 (Studi Kasus : Di Muara Sungan Citanduy, Segara Anakan)

Tabel 1. Karakteristik SPOT 6 Untuk Daerah Visible

Table 1. SPOT 6 Characteristic for Visible Area

\begin{tabular}{cccc}
\hline NO & KANAL & PANJANG.GELOMBANG & RESOLUSI \\
\hline 1 & Blue & $0,450-0,525 \mu \mathrm{m}$ & $6 \mathrm{~m}$ \\
2 & Green & $0,430-0,590 \mu \mathrm{m}$ & $6 \mathrm{~m}$ \\
3 & Merah & $0,625-0,695 \mu \mathrm{m}$ & $6 \mathrm{~m}$ \\
4 & NIR & $0,760-0,890 \mu \mathrm{m}$ & $6 \mathrm{~m}$ \\
\hline
\end{tabular}

Sumber : http://www.satimagingcorp.com/satellite-sensors/spot-6/ Multispectral Imagery (4 bands)

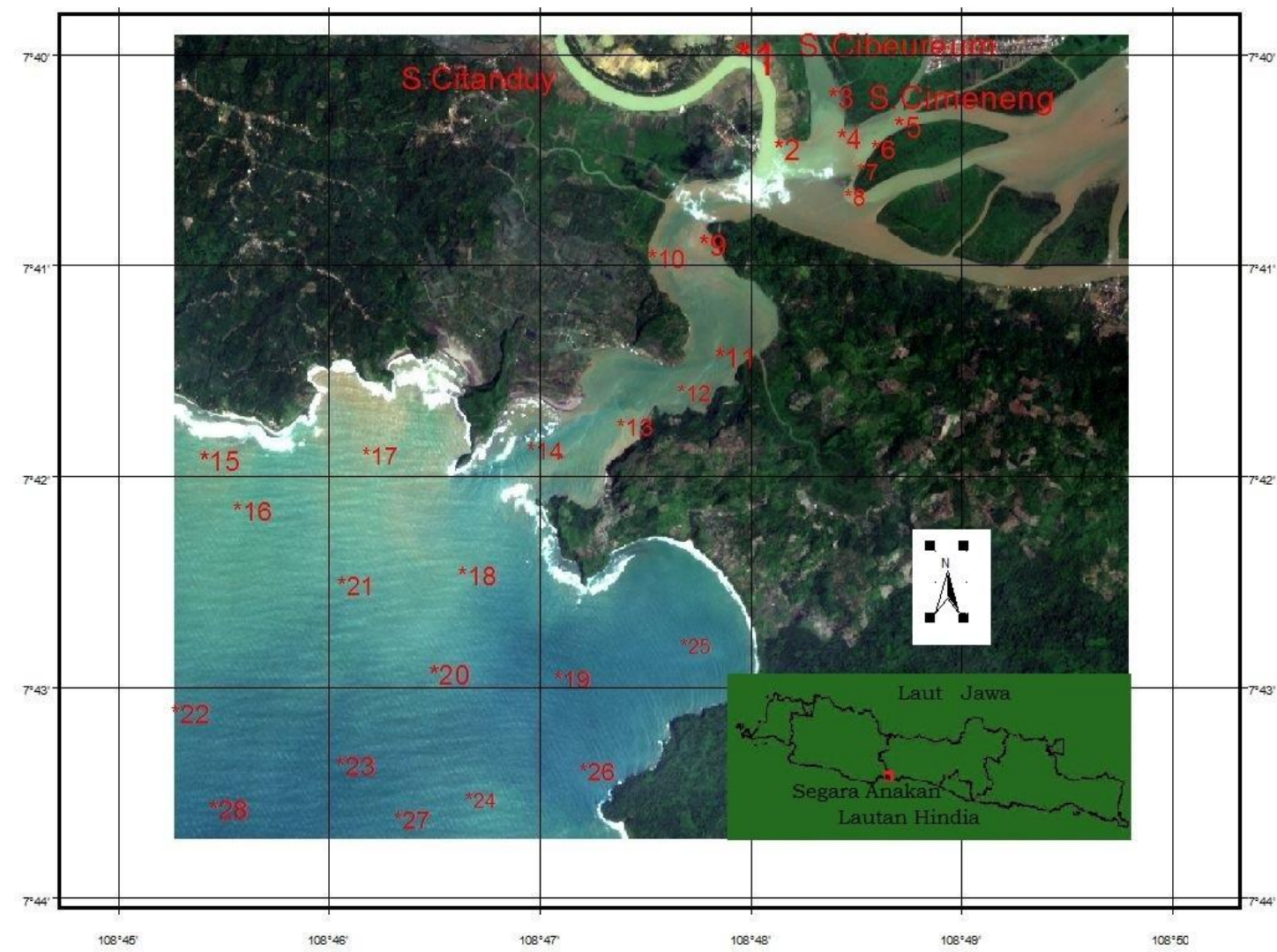

Sumber Citra : Pusat Teknologi dan Data Penginderaan Jauh. Jl. LAPAN No. 70, Pekayon, Pasar Rebo, Jakarta 13710.

Gambar 1. Citra SPOT 6 RGB 321 Tanggal 10 Januari dan Lokasi (*) Penelitian di Muara Citanduy Sagara Anakan.

Picture 1. SPOT 6 Imagery 6 RGB 321 on January 10th at Location (*) Research on River Estuary Citanduy Sagara Anakan

\section{Metode}

Metode yang digunakan adalah menggunakan pendekatan algoritma yang menggunakan persamaan fungsi ekponensial dari satu kanal band tunggal.Model ini merupakan model dari Budhiman (2005) yaitu algoritma konsentrasi TSM menggunakan bio-optical model yang dapat digunakan untuk menghasilkan data set $\mathrm{R}(0-)$ pada setiap senssor kanal sebagai fungsi dari meningkatnya konsentrasi TSM. Sehingga hubungan korelasi antara nilai TSM dan nilai spektral pada masing-masing kanal adalah algoritma berdasarkan pada satu kanal. Hubungan antara $\mathrm{R}(0-)$ model konsentrasi TSM pada ASTER ditunjukkan pada Gambar 2. Pada Gambar 2 menunjukkan bahwa kanal merah dapat memberikan identifikasi nilai konsentrasi TSM yang baik. Kanal merah sensitif terhadap nilai konsentrasi TSM yang tinggi (berdasarakandynamic range yang terlihat pada Gambar 2). Hasil ini menyerupai hasil penelitianDekker et. al.(1998) ; Ambarwulan, (2002); danvan der Woerd dan Pasterkamp (2002). 


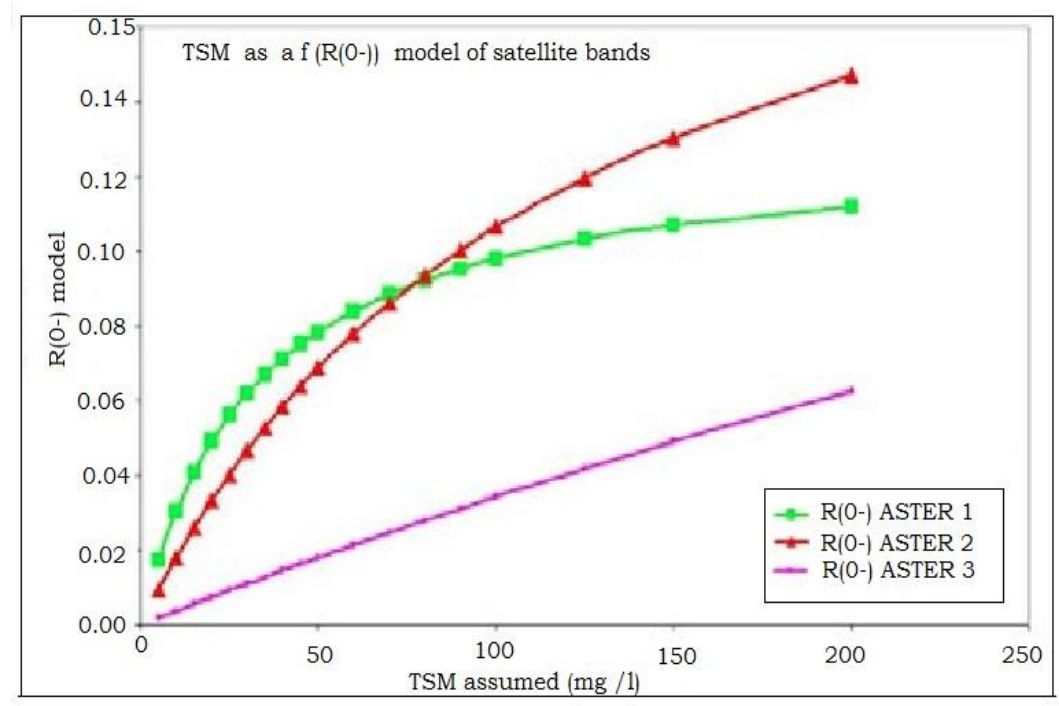

Sumber : Budhiman S., 2005,

Gambar 2. Hubungan antara R(0-) model konsentrasi TSM pada ASTER

Picture 2. Correlation between $\mathrm{R}(0-)$ concentration model TSM on ASTER

Kanal hijau terlihat sensitif untuk mengukur nilai konsentrasi TSM yang rendah (misalnya: kurang dari $50 \mathrm{mg} / \mathrm{L}$ ). Dari gambar tersebut terlihat hubungan antara kanal Merah dan Hijau membentuk kurva eksponensial, tetapi untuk kanal NIR, hubungan yang terbentuk mendekati linear. Fungsi eksponensial kemudian digunakan untuk mendapatkan algoritma TSM pada perairan Delta Mahakam berdasarkan nilai $\mathrm{R}(0-)$. Keuntungan dari hubungan eksponensial adalah nilai-nilai TSM yang negatif dan atau sangat tinggi akan dapat dihindari. Persamaan

TSM $=8.1744 * \exp (23.738 *$ band red)...............(1)memperlihatkan algoritma yang didapat untuk memetakan sebaran TSM di perairan Delta Mahakam, dengan koefisien determinasi $(\mathrm{R} 2)=0.94$.

Pada data SPOT 6 penurunan model TSM dilakukan menggunakan regresi antara hasil penurunan algoritma TSM dengan test area piksel konsentrasi TSM pada citra SPOT 6. Reflektansi citra yang digunakan adalah data SPOT 6 kanal 3, yaitu kanal visibleband merah, dengan panjang gelombang 0.636$0.673 \mu \mathrm{m}$. Model yang digunakan merupakan acuan dari model Budhiman (2004) yaitu model eksponensial, yang kemudian dimodikasi ke data SPOT 6 sesuai dengan karakteristiknya. Pengembangan metode yang dilakukan dengan data SPOT 6 bertujuan untuk meningkatkan keakurasian karena resolusi spasial yang dimiliki citra SPOT 6 lebih tinggi dari pada citra Landsat yang selama ini digunakan.

\section{Hasil dan Pembahasan}

Hasil pengolahan citra SPOT 6 dengan menurunkan bentuk persamaan $8.1744 * \exp (23.738 *$ band $\quad$ red $)$ dan memodikasikan ke data SPOT 6 hasilnya menjadi dalam bentuk algoritma persamaan if nir $<=0.242442$ then $8.1744 * \exp (23.738 *$ band red) else null........(2),dimana : nir $=0.242442$ adalah nilai reflektan minimum, untuk memisahkan darat dan air.Hasil penurunan algoritma persamaan (2) dapat diperoleh bentuk citra sedimen tersuspensi TSM ditunjukkan pada Gambar 2. Semua hasil pengolahan dari hasil perhitungan model persamaan (2)dan hasil pengukuran langsung tiap per-piksel disimpan dalam Tabel 2 . Pemilihan lokasi ini diupayakan dapat merepresentasikan kondisi nilai sedimen tersuspensi TSM di sekitar perairan muara sungai Citanduy yang sebelumnya telah mengalir melewati laguna Segara Anakan. Jumlah titik pengukuran pengambilan sampel yang diekstraksi sebanyak 28 titik dengan parameter yang diukur adalah nilai reflektansi kanal 3 (band merah) dari citra SPOT 6. 
Nana Suwargana :Pengembangan Model Total Suspended Matter (TSM) Menggunakan Data Satelit SPOT 6 (Studi Kasus : Di Muara Sungan Citanduy, Segara Anakan)

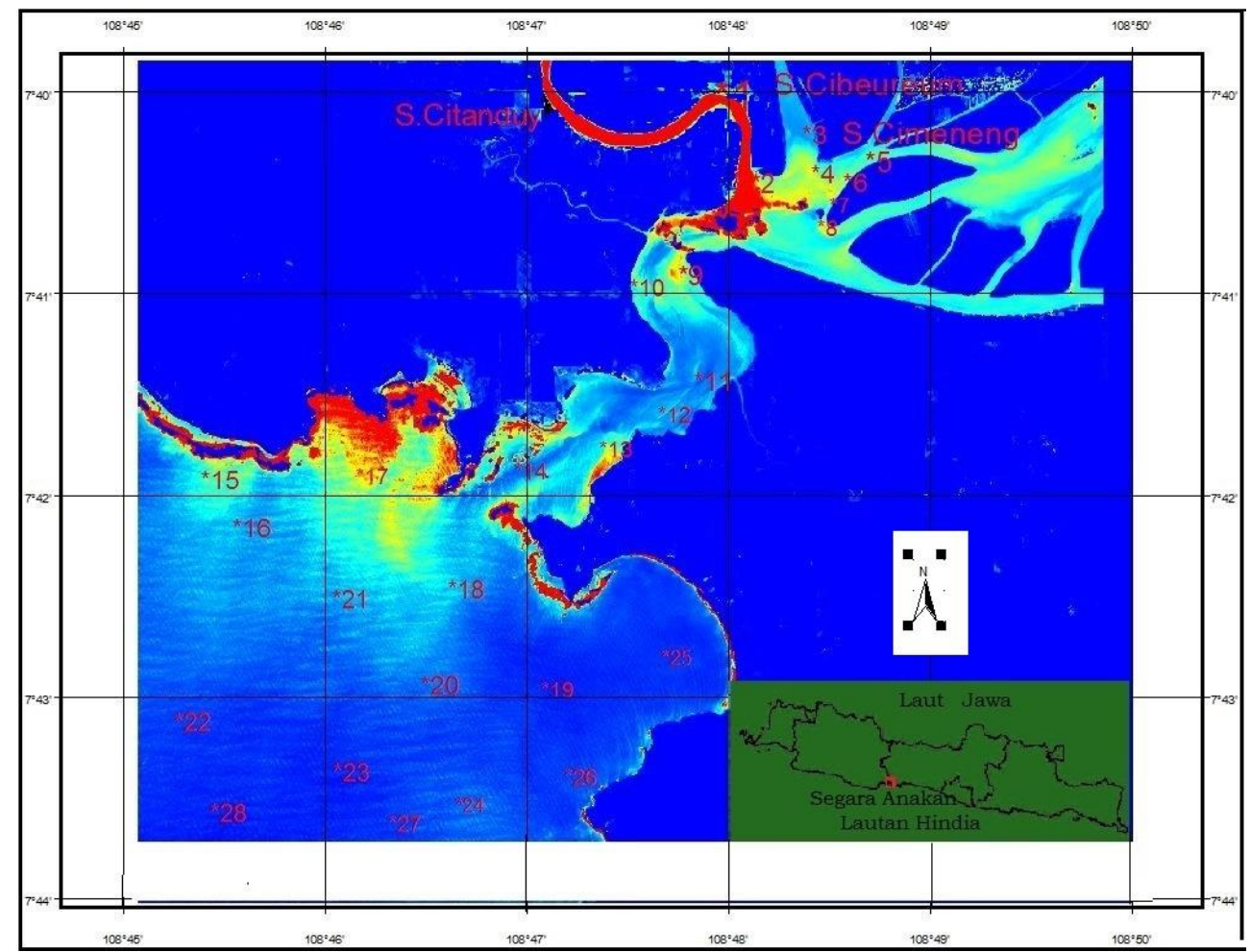

Gambar 2. Konsentrasi TSM SPOT 6 tanggal 10 Januari 2015berdasarkan algoritmaif nir $<=0.242442$ then $8.1744 * \exp \left(23.738^{*}\right.$ band merah) else null

Picture 2. TSM Concentration TSM SPOT 6 on January $10^{\text {th }} 2015$ based on algorithm if nir $<=0.242442$ then $8.1744 * \exp (23.738 *$ red band) else null

Nilai TSM hasil perhitungan algoritma model persamaan if $\mathrm{nir}<=0.242442$ then $8.1744 * \exp (23.738 *$ band red) else null memperoleh nilai TSM yang bervariasi dengan besaran nilai sedimen tersuspensi TSM SPOT 6 berkisar antara $0-130 \mathrm{mg} / \mathrm{L}$, hasilnya ditunjukkan pada Tabel 2. Hasil pengujian TSM citra SPOT 6 antara hasil penurunan model algoritma persamaan nir $<=0.242442$ then $8.1744 * \exp (23.738 *$ band red $)$ dengan TSM test pengukuran langsung per-piksel menunjukkan hasil yang significant dan ditunjukkan pada Gambar 3. Besaran nilai TSM dari 28 (dua puluh delapan) titikpengamatan di citra SPOT 6 memberikan pola TSM yang berfluktuasi. Dari analisis citra SPOT 6 dan hubungan yang diperoleh dari hasil TSM model perhitungan algoritma dengan hasil TSM test per-piksel dari citra SPOT 6 diperoleh persamaan $\mathrm{y}=1,117 \mathrm{x}-16,09$ dengan koefesien determinanasi $\mathrm{R}^{2}=0,925 \%$. Hasil penurunan persamaan regresi ini, menunjukkan hasil yang signifikan sehingga nampak pola hasil koreksinya sangat bagus. Dari hasil penurunan TSM menunjukkan TSM yang rendah berada di lokasi kearah laut lepas yaitu disekitar titik pengamatan no 28. Sedangkan TSM yang tinggi berada di sekitar muara diantaranya ditik 17 dan disekitar sungai Citanduy dititik no 1 . 
Tabel 2. Data hasil pengamatan dan perhitungan model persamaan if nir $<=0.242442$ then $8.1744^{*} \exp$ (23.738*band merah) else null yang diperoleh dari data SPOT 6 langsung tiap per-piksel.

Table 2. Observation and calculation data of equation model if nir $<=0.242442$ then $8.1744 *$ exp (23.738*red band) else null which obtained from SPOT 6 direct data on each pixel

\begin{tabular}{|c|c|c|c|c|c|c|c|c|c|}
\hline \multirow[b]{2}{*}{ No } & \multirow[b]{2}{*}{ Lokasi } & \multirow{2}{*}{$\begin{array}{c}\text { Spot } 6 \\
\text { B3 }\end{array}$} & \multicolumn{2}{|l|}{ TSM } & \multirow[b]{2}{*}{ No } & \multirow[b]{2}{*}{ Lokasi } & \multirow{2}{*}{$\begin{array}{c}\text { Spot } 6 \\
\text { B3 }\end{array}$} & \multicolumn{2}{|l|}{ TSM } \\
\hline & & & $\begin{array}{c}\text { Perhitungan } \\
\text { algoritma }\end{array}$ & $\begin{array}{c}\text { Test } \\
\text { piksel }\end{array}$ & & & & $\begin{array}{c}\text { Perhitungan } \\
\text { algoritma }\end{array}$ & $\begin{array}{c}\text { Test } \\
\text { piksel }\end{array}$ \\
\hline \multirow[t]{6}{*}{1} & t1a & 0,0903 & 69,74988 & 69 & 5 & t5 & 0,08229 & 57,6721433 & 42 \\
\hline & $\mathrm{t} 1 \mathrm{~b}$ & 0,08799 & 66,02813 & 60 & 6 & t6 & 0,08889 & 67,4539452 & 50 \\
\hline & $\mathrm{t} 1 \mathrm{c}$ & 0,11479 & 124,7435 & 128 & 7 & $\mathrm{t} 7$ & 0,0903 & 69,7498766 & 59 \\
\hline & t1d & 0,11559 & 127,135 & 128 & 8 & t8 & 0,09849 & 84,7181506 & 76 \\
\hline & t1e & 0,10989 & 111,0458 & 111 & 9 & t9 & 0,1088 & 108,209445 & 101 \\
\hline & $\mathrm{t} 1 \mathrm{f}$ & 0,10769 & 105,3955 & 103 & 10 & $\mathrm{t} 10$ & 0,08969 & 68,7471631 & 50 \\
\hline \multirow[t]{6}{*}{2} & $\mathrm{t} 2 \mathrm{a}$ & 0,0903 & 69,74988 & 59 & 11 & $\mathrm{t} 11$ & 0,0621 & 35,7126173 & 16 \\
\hline & $\mathrm{t} 2 \mathrm{~b}$ & 0,08659 & 63,86987 & 50 & 12 & $\mathrm{t} 12$ & 0,0709 & 44,0091889 & 34 \\
\hline & $\mathrm{t} 2 \mathrm{c}$ & 0,08739 & 65,09437 & 50 & 13 & $\mathrm{t} 13$ & 0,09309 & 74,5257476 & 42 \\
\hline & $\mathrm{t} 2 \mathrm{~d}$ & 0,09279 & 73,99691 & 59 & 14 & $\mathrm{t} 14$ & 0,0592 & 33,3368653 & 43 \\
\hline & $\mathrm{t} 2 \mathrm{e}$ & 0,0894 & 68,27553 & 50 & 15 & $\mathrm{t} 15$ & 0,08169 & 56,8565524 & 50 \\
\hline & $\mathrm{t} 2 \mathrm{f}$ & 0,0877 & 65,57515 & 50 & 16 & $\mathrm{t} 16$ & 0,0746 & 48,0493713 & 34 \\
\hline \multirow[t]{6}{*}{3} & $\mathrm{t} 3 \mathrm{a}$ & 0,0701 & 43,18132 & 46 & 17 & $\mathrm{t} 17$ & 0,09969 & 87,1660981 & 101 \\
\hline & $\mathrm{t} 3 \mathrm{~b}$ & 0,0675 & 40,5968 & 38 & 18 & $\mathrm{t} 18$ & 0,0709 & 44,0091889 & 25 \\
\hline & $t 3 c$ & 0,06549 & 38,70527 & 35 & 19 & $\mathrm{t} 19$ & 0,0447 & 23,6287184 & 8 \\
\hline & $\mathrm{t} 3 \mathrm{~d}$ & 0,0694 & 42,46972 & 40 & 20 & $\mathrm{t} 20$ & 0,0615 & 35,2075748 & 25 \\
\hline & t3e & 0,07119 & 44,31319 & 41 & 21 & $\mathrm{t} 21$ & 0,06889 & 41,9586694 & 25 \\
\hline & $\mathrm{t} 3 \mathrm{f}$ & 0,06639 & 39,54108 & 36 & 22 & $\mathrm{t} 22$ & 0,0575 & 32,0183524 & 16 \\
\hline \multirow[t]{6}{*}{4} & $\mathrm{t} 4 \mathrm{a}$ & 0,08489 & 61,34374 & 60 & 23 & $\mathrm{t} 23$ & 0,04439 & 23,455478 & 8 \\
\hline & $\mathrm{t} 4 \mathrm{~b}$ & 0,0815 & 56,60069 & 52 & 24 & $\mathrm{t} 24$ & 0,0533 & 28,9801077 & 16 \\
\hline & $\mathrm{t} 4 \mathrm{c}$ & 0,08229 & 57,67214 & 52 & 25 & $\mathrm{t} 25$ & 0,0515 & 27,7679159 & 8 \\
\hline & $\mathrm{t} 4 \mathrm{~d}$ & 0,0863 & 63,43169 & 60 & 26 & $\mathrm{t} 26$ & 0,0515 & 27,7679159 & 8 \\
\hline & $\mathrm{t} 4 \mathrm{e}$ & 0,0863 & 63,43169 & 62 & 27 & $\mathrm{t} 27$ & 0,048 & 25,5541122 & 8 \\
\hline & $\mathrm{t} 4 \mathrm{f}$ & 0,0816 & 56,73521 & 52 & 28 & $\mathrm{t} 28$ & 0,04639 & 24,5959076 & 8 \\
\hline
\end{tabular}

Ekstraksi informasi sedimen tersuspensiTSM pada citra satelit SPOT 6 yaitu memanfaatkan kanal band merah. Seperti yang diungkapkan oleh Budiman (2004) dalam penelitiannya melaporkan bahwa algoritma untuk konsentrasi TSM menggunakan biooptical model (analycal methode) yang dapat digunakan untuk menghasilkan irradiance reflectance di bawah permukaan air atau data set $\mathrm{R}(0-)$ yang pada setiap sensor kanal sebagai fungsi dari meningkatnya konsentrasi TSM. Hubungan yang dibangun adalah korelasi antara nilai TSM dan nilai spektral pada masing-masing kanal, sehingga algoritma yang digunakan adalah algoritma berdasarkan pada satu kanal. Pada Gambar 4 menunjukkan korelasi antara TSM hasil perhitungan algoritma $\quad \operatorname{nir}<=\quad 0.242442$ then
$8.1744 * \exp (23.738 *$ band red $)$ dengan reflektansi kanal 3 band merah pada citra SPOT 6. Gambar 4 ini dapat menunjukkan bahwa kanal merah dapat memberikan identifikasi nilai konsentrasi TSM yang baik. Sehingga kanal merah sensitif terhadap nilai konsentrasi TSM yang tinggi berdasarkan dinamik range yang telihat pada Gambar 4. Dari analisis citra SPOT 6 dan hubungan yang diperoleh dari hasil TSM model perhitungan algoritma dengan hasil TSM test per-piksel dari citra SPOT 6 diperoleh persamaan $0,008 x^{0.564}$ dengan koefesien determinasi $\left(R^{2}\right)$ $=0,980 \%$. Ini membuktikan bahwa kanal merah pada citra SPOT 6 dapat memberikan identifikasi untuk menentukan konsentrasi TSM. 
Nana Suwargana :Pengembangan Model Total Suspended Matter (TSM) Menggunakan Data Satelit SPOT 6 (Studi Kasus : Di Muara Sungan Citanduy, Segara Anakan)

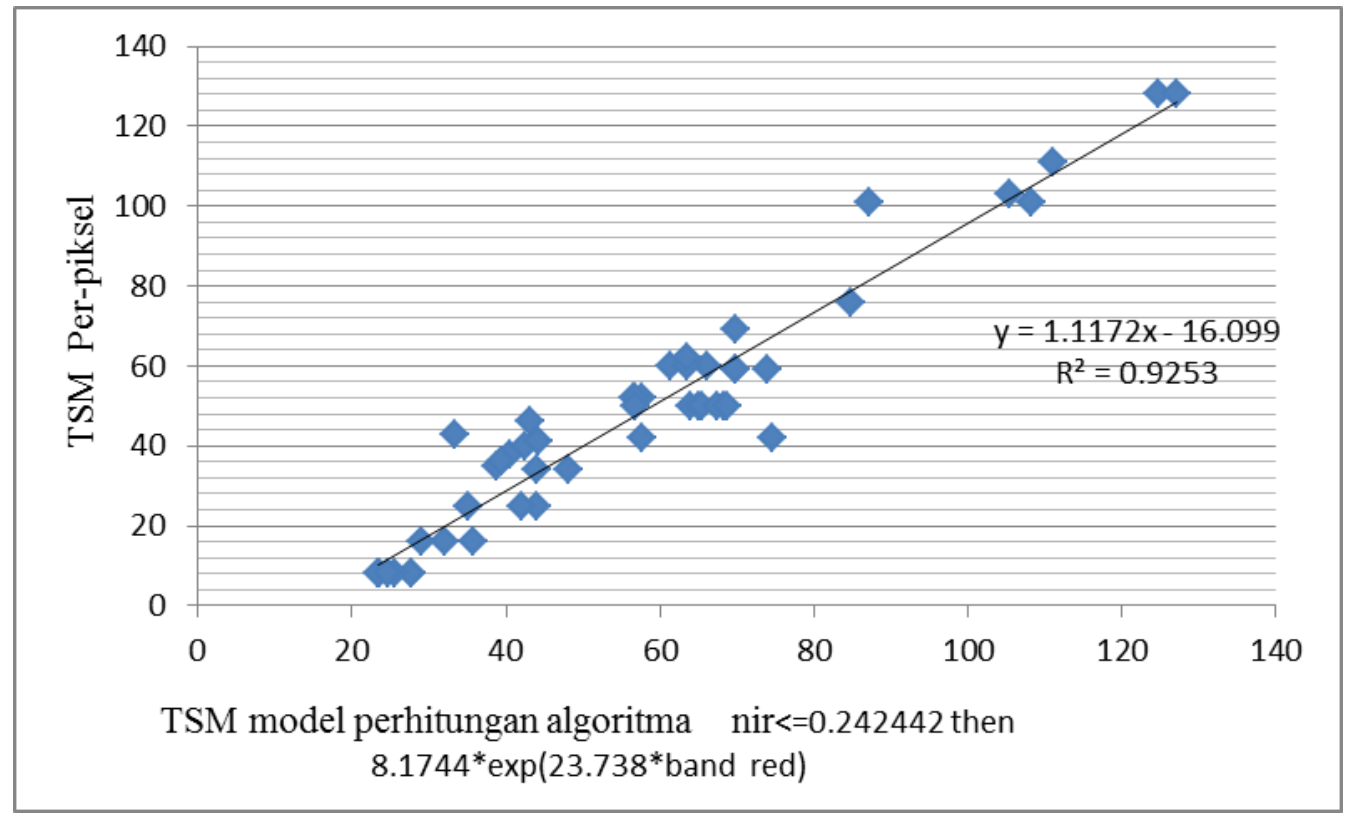

Gambar 3. Hubungan antara TSM model algoritma i $<<=0.242442$ then $8.1744 * \exp (23.738 *$ band red $)$ dengan TSM per-piksel.

Picture 3. Correlation between algorithm model TSM i2 $<=0.242442$ then $8.1744 * \exp (23.738 *$ red band) with TSM per pixel

Kemudian pada penelitian ini dibuat suatu korelasi antara nilai reflekstan pada kanal band merah citra SPOT 6 terhadap titik-titik nilai TSM pada setiap piksel, hasilnya juga menunjukkan suatu kurva eksponensial yang ditunjukkan Gambar 5. Dari analisis citra SPOT 6 dan hubungan antara hasil TSM model perhitungan algoritma dengan hasil TSM yang diperoleh dari setiap piksel titik-titik pengamatan dicitra SPOT 6 diperoleh persamaan $0,24 \mathrm{x}^{0.316}$ dengan koefesien determinasi $\mathrm{R}^{2}=0,903 \%$. Hasil penurunan persamaan regresi bentuk eksponen ini, menunjukkan hasil yang signifikan sehingga nampak pola hasil koreksinya mendekati hampir sama dengan Gambar 4. Jadi pengamatan pada Gambar 5 ini menunjukkan bahwa kanal merah dapat memberikan identifikasi nilai konsentrasi TSM yang baik dan sama dengan Gambar 4. Kanal merah sensitif terhadap nilai konsentrasi TSM yang tinggi berdasarkan dinamik range yang telihat pada Gambar 5. Namun dari Gambar 5 sedikit perbeda dan lebih rendah. Hal ini disebabkan kemungkinan dalam melakukan test area menentukan posisi lokasi setiap titik piksel mengalami sedikit pergeseran. Gambar 4 menunjukkan TSM paling rendah berada pada $20 \mathrm{mg} /$ Ldengan reflektan berada pada 0,04. Semakin naik nilai TSM hingga $130 \mathrm{mg} / \mathrm{L}$, maka naik pula nilai reflektan band merah membentuk garis exponensial hingga reflektan 0,12 . Namun pada Gambar 5 menunjukkan TSM paling rendah pada pada $5 \mathrm{mg} / \mathrm{L}$ dengan reflektan sama berada pada 0,04. Juga sama semakin naik nilai TSM hingga $130 \mathrm{mg} / \mathrm{L}$ maka naik pula nilai reflektan band merah membentuk garis exponensial hingga reflektan 0,12. Hal ini menunjukkan bahwa kanal band merah pada citra SPOT 6 cocok untuk penelitian menentuan nilai TSM. Hal ini sesuai dengan hasil yang menyerupai dari penelitian Dekker dkk (1998);Ambarwulan (2002); dan van der Woerd dan Pasterkamp (2002). 


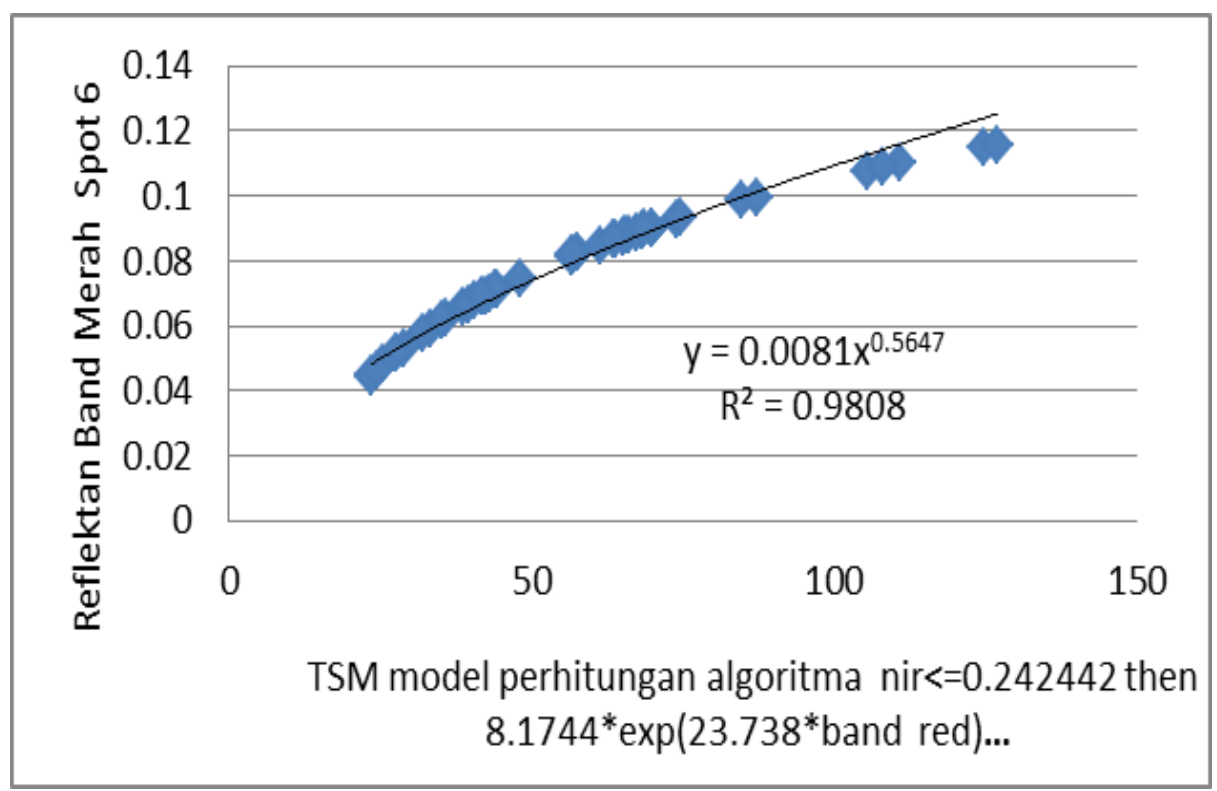

Gambar 4.Korelasi antara TSM hasil perhitungan algoritma nir $<=$ then $8.1744 * \exp (23.738 *$ band red)dan reflektansi kanal 3 band merah citra SPOT 6.

Picture 4. Correlation betweenalgorithm calculation TSM nir $<=$ then $8.1744 * \exp \left(23.738^{*}\right.$ red band $)$ and canal reflectance 3 imagery red band SPOT 6

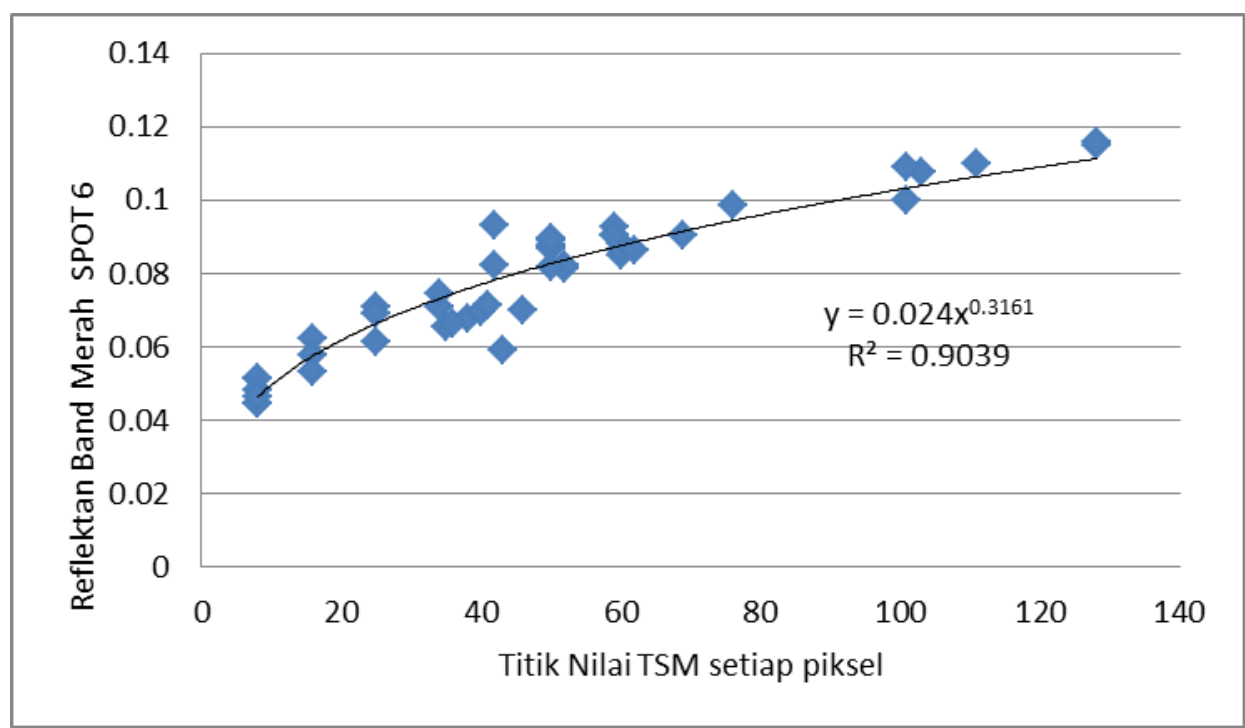

Gambar 5 Korelasi antara nilaiTSMper-piksel dan reflektansi Band 3 citrapada SPOT 6 Picture 5. Correlation between TSM per pixel and imagery Band 3 reflectance on SPOT 6

Untuk mengaplikasikan model TSM tersebut dan melihat besarnya tingkat TSM pada setiap titik pengamatan dapat ditentukan dengan membuat klasifikasi. Ini dapat memberikan gambaran tingkat distribusi TSM yang lebih jelas dengan kondisi riil yang lebih luas dilokasi penelitian. Informasi objek yang dihasilkan juga lebih luas dan mampu membedakan objek TSM minimum dan TSM maksimum. Oleh karena itu, klasifikasi dengan cara perhitungan nilai reflektan dapat menghasilkan klasifikasi yang lebih baik dan mampu menentukan lebih banyak kelas-kelas TSM yang diinginkan. Untuk mendapatkan hasil yang optimum digunakan klasifikasi dengan model klasifikasi unsupervised dan pengkelasan proses awal dibuat 30 kelas. Hasil klasifikasi tersebut selanjutnya dilakukan editing yang berulang-ulang. Hasil akhir editing kemudian dilakukan reklasifikasi, hasilnya dikelaskan menjadi 10 kelas, yaknikelas 1 (0-10 $\mathrm{mg} / \mathrm{L})$, kelas 2 (10-15 $\mathrm{mg} / \mathrm{L})$, kelas 3 (15-30 mg/L), kelas 4 (30-45 $\mathrm{mg} / \mathrm{L})$, kelas 5 (45-60 mg/L), kelas 6 (60-75 
Nana Suwargana :Pengembangan Model Total Suspended Matter (TSM) Menggunakan Data Satelit SPOT 6 (Studi Kasus : Di Muara Sungan Citanduy, Segara Anakan)

$\mathrm{mg} / \mathrm{L})$, kelas 7 (75-90 mg/L), kelas 8 (90-105 $\mathrm{mg} / \mathrm{L})$, kelas 9(105-120 mg/L), kelas 10 (120$130 \mathrm{mg} / \mathrm{L}$ ) ditunjukkan pada (Gambar 6). Pada citra Gambar 6 nampak kelas paling rendah adalah kelas 1warna biru dengan konsentrasi berkisar $0-10 \mathrm{mg} / \mathrm{L}$ dan nilai konsentrasi paling tinggi adalah kelas 10: warna coklat dengan konsentrasi berkisar (120-130 mg/L).

Informasi spasial distribusi TSM di muara Citanduy nampaknya menunjukkan pergerakan yang bergerombol mengikuti arus air yang keluar menuju laut lepas. Pengamatan dilokasi t1 dengan pengamatan di sub lokasi: t1a, t1b, t1c, t1d, tle dan t1f menunjukan bahwa besaran TSM menunjukkan TSM cukup tinggi, artinya disini sungai Citanduy banyak membawa material lumpur yang sangat tinggi lihat Tabel 2. Kemudian pada titik pengamatan t17 menunjukkan besaran TSM berkisar 101 $\mathrm{mg} /$ Lini juga menunjukkan bahwa lumpur material yang tinggi berkumpul dilekukan sisi pantai. TSM yang paling rendah adalah di titik pengamatan $\mathrm{t} 19$ dengan TSM berkisar 8 mg/Ldan t28dengan TSM berkisar 8
mg/L.Gambar. 7 menunjukkan lokasi penelitian dengan latar belakang muara sungai Citanduy disekitar lokasi 10 dan 11 dengan latar belakang airnya keruh dengan TSM berkisar 35,71 mg/Ldan 78,74 mg/L. Data SPOT 6 ini merupakan data musim basah yaitu bulan Januari 2015. Terlihat konsentrasi yang tinggi terdapat pada sungai Citanduy yang mengalir menuju Muara Segara Anakan.Proses sedimentasi di Segara Anakan dipengaruhi oleh pasang surut. Saat pasang menyebabkan pergerakan material lumpur dari muara Citanduy bergerak ke utara dan pada saat yang sama aliran sungai Cibeureun dan sungai Cimeneng yang mengalir keselatan kembali lagi bergerak mengalir ke utara bersamaan dengan membawa lumpur dari sungai Citanduy. Kemudian pada saat surut, kembali lagi bergerak mengalir keselatan sambil meninggalkan lumpur di daerah laguna menuju laut lepas pantai. Proses kejadian alam ini berlangsung setiap tahun sehingga laguna Segara Anakan semakin sempit.

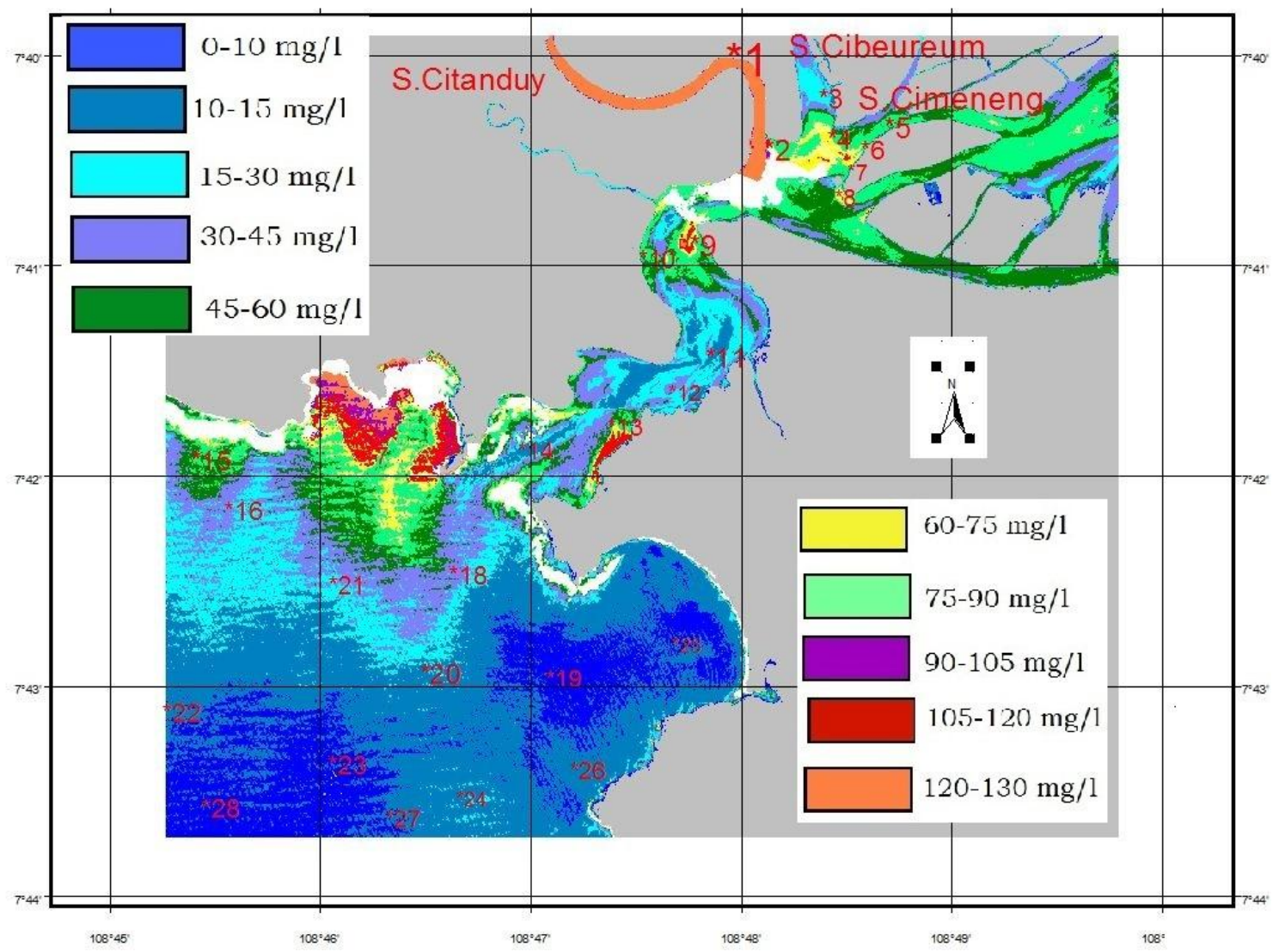

Gambar 6. Klasifikasi Konsentrasi TSM SPOT 6 Tanggal 10 Januari 2015

Picture 6. Concentration clasification TSM SPOT 6 on January 10th 2015 


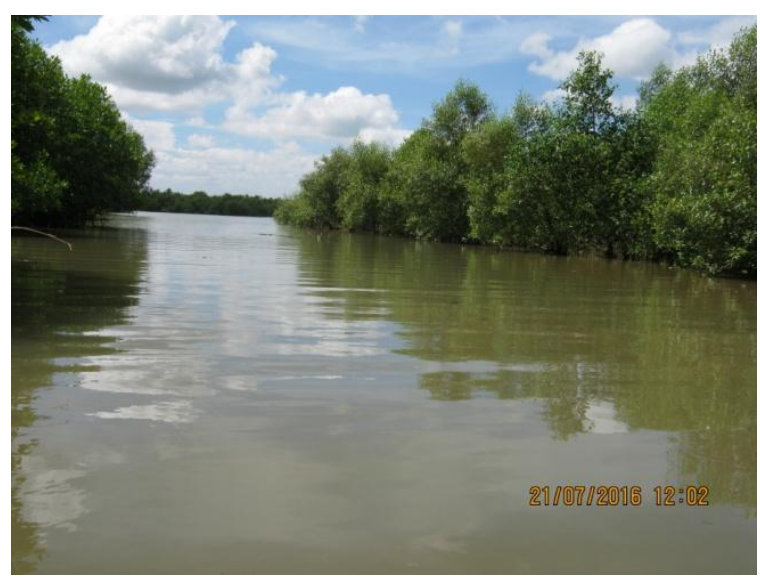

Lokasi 10

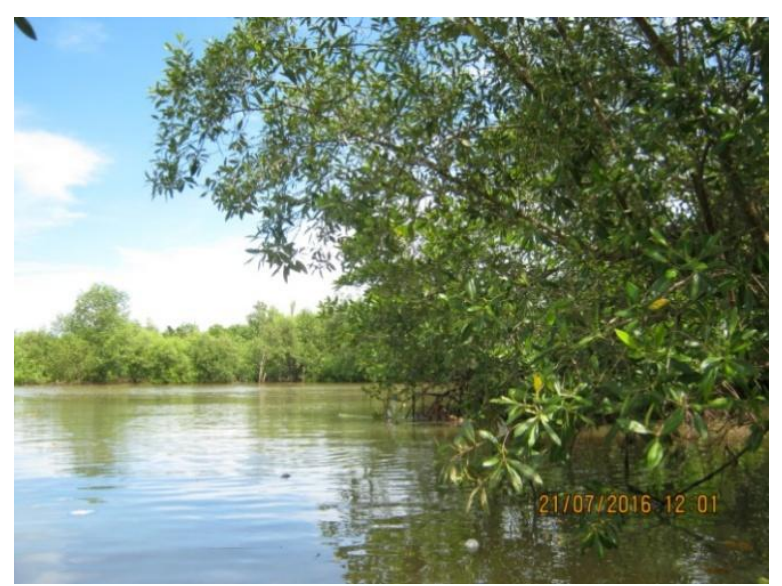

Lokasi 11

Gambar 7. Muara Citanduy disekitar titik 10 dan 11 nilai TSM berkisar antara 35,71 mg/L dan 78,74 $\mathrm{mg} / \mathrm{L}$.

Picture 7. River estuary around 10 and 11 point have TSM About $35,71 \mathrm{mg} / \mathrm{L}$ to $78,74 \mathrm{mg} / \mathrm{L}$.

\section{Kesimpulan}

Hasil analisis menunjukkan bahwa kanal merah sensitif terhadap nilai konsentrasi TSM terbukti pada citra SPOT 6 kanal merah dapat memberikan identifikasi nilai konsentrasi TSM yang baik. Berdasarkan hasil test area sebanyak 28 titik pengamatan, diperoleh korelasi antara nilai TSMpada setiap titik-titik piksel pengamatan terhadap reflektansi band merahpada citra SPOT 6diperoleh persamaan $0,24 x^{0.316}$ dengan koefesien determinasi $R^{2}=$ $0,903 \%$ menunjukkan hasil yang cukup signifikan.

Konsentrasi TSM yang tinggi dominan datang dari sungai Citanduy dan kedua dari sungai Cibeureum dan sungai Cimeneng. Proses sedimentasi di Segara Anakan dipengaruhi oleh pasang surut. Saat pasang menyebabkan pergerakan material lumpur dari muara Citanduy bergerak ke utara dan pada saat yang sama aliran sungai Cibeureun dan sungai Cimeneng yang mengalir keselatan kembali lagi bergerak mengalir ke utara bersamaan dengan membawa lumpur dari sungai Citanduy. Kemudian pada saat surut, kembali lagi bergerak mengalir keselatan menuju laut Samudra Hindia dan sebagian material lumpur tertinggal daerah laguna.

\section{Ucapan Terima Kasih}

Penulis mengucapkan terima kasih kepada Masyarakat Majingklak Kalipucang Jawa Barat yang telah banyak membantu dalam menyurvei aliran muara Citanduy serta kepada Syarif Budhiman, S.Si, M.Sc atas bantuan pemakaian data dan arahan dalam penelitian ini.

\section{Daftar Pustaka}

Achiruddin, I., T. Hariyanto, dan C. Nurdjati, 2005. Pemantauan Perubahan Garis Pantai di Pantai Timur Surabaya dengan Teknologi Penginderaan Jauh. Geoid Vol. 1, No. 1, Surabaya. ISSN : 1858-2281. Hal 24 -29 .

Ambarwulan, W, 2002. Mapping of TSM concentrations from SPOT and Landsat TM satellite images for Integrated Coastal Zone Management in Teluk Banten, Indonesia. MSc Thesis. ITC, Enschede, The Netherlands; $130 \mathrm{p}$.

Budhiman S., 2005, Pemetaan Sebaran Total Suspended Mater (TSM) Menggunakan Data Aster dengan Pendekatan BioOptical Model. Petemuan Ilmiah Tahunan MAPIN XIV. Pemanfaatan Efektif Penginderaan Jauh Untuk Peningkatan Kesejahteraan Bangsa. Gedung Rektorat lt.3 Kampus Institut Teknologi Sepuluh Nopember Surabaya, 14-15 September 2005.

Carolita, I., E. Parwati., B. Trisakti, T. Kartika, dan G. Nugroho, 2005. Model Prediksi Perubahan Lingkungan Di Kawasan Perairan Segara Anakan. Prosiding PIT MAPIN $X I V$. Pemanfaatan Efektif Penginderaan Jauh Untuk Peningkatan Kesejahteraan 
Nana Suwargana :Pengembangan Model Total Suspended Matter (TSM) Menggunakan Data Satelit SPOT 6 (Studi Kasus : Di Muara Sungan Citanduy, Segara Anakan)

Bangsa. JilidIII, Teknologi Informasi Spasial, Surabaya. Hal $173-178$.

Dekker, A.G., S.W.M. Peters, M. Rijkeboer, and H. Berghuis. 1998. Analytical processing of multitemporal SPOT and Landsat images for estuarine management in Kalimantan Indonesia. In: Nieuwnhuis, G.J.A., R.A. Vaughan, and M. Molenaar (Eds.). 1999. Operational Remote Sensing for Sustainable Development. A.A. Balkema Publishers, Rotterdam, The Netherlands; pp.315-323

Effendi, H. 2003. Telaah Kualitas Air Bagi Pengelolaan Sumber Daya dan Lingkungan Perairan. Kanisius. Yogyakarta.

http://www.satimagingcorp.com/satellitesensors/spot-6/SPOT-6 Satelitte Sensor Multispectral Imagery (4 bands)

Parwati Ety, Bambang Trisakti, Ita Carolina, Tatik, Sri Harini dan Ratih Dewanti. 2006. Analisis Hubungan Penutupan/Penggunaan Lahan dengan Total Suspended Matter (TSM) Kawasan Perairan Segara Anakan Menggunakan Data Inderaja. Jurnal
Penginderaan Jauh. Vol 3. No 1 Juni 2006.

Parwati Ety dan Purwanto Anang Dwi. 2014, Analisis Algoritma Ekstraksi Informasi TSM Menggunakan Data Landsat 8 di Perairan Berau. Deteksi Parameter Geobiofisik dan Diseminasi Penginderaan Jauh. Seminar Nasional Penginderaan Jauh 2014.

Pustekdata. Pusat Teknologi dan Data Penginderaan Jauh.2014. Jl. LAPAN No. 70, Pekayon, Pasar Rebo, Jakarta 13710 .

Tassan, S., and Ribera d'Alcala, 1993. Water Quqlity Monitoring by Thematic Mapper in Coastal Enviromental: Performance Analysis of Local Biooptical Algorithm and Athmospericn Correction Procedure Remote Sensing Enviroment. 45,pp.117-191.

Van der Woerd, H, and R. Pasterkamp. 2002. A rigorous method to retrieve TSM concentrations from multi-temporal spot images in highly - turbid coastal waters. Paper on the $11^{\text {th }}$ Australian Remote Sensing and Photogrammetry Conference (ARSPC), September $2^{\text {nd }}$ to $5^{\text {th }} 2002.11 \mathrm{p}$. 